\title{
The Effect Of Flash Animation On The Students' Ability In Writing Descriptive Text
}

\author{
Nur Rahmadani ${ }^{1}$, Nurhaeni ${ }^{2}$ \\ \{danieyra18@gmail.com ${ }^{1}$,nurhaeni030@gmail.com ${ }^{2}$ \} \\ Sari Mulia University of Banjarmasin ${ }^{1}$, Sari Mulia University of Banjarmasin ${ }^{2}$
}

\begin{abstract}
In English, there are four skills which must be mastered, they are listening, speaking, reading, and writing. One of the language skills is writing that important for learners to practice their capability and their understanding, how to send idea, and how to arrange words well. Most teachers have objectives to develop student's capability. The objective of this study was to find out the effect of using flash animation as a media on writing descriptive text of the eighth grade students.

This study used quasi experimental research with non randomized-groups pretest and post-test control group design as the research design. The number of population was 195 students. The sample of this study was class VIII- 1 as the experimental group, there were 35 students. Class VIII-5 as the control group, there were 32 students. In this study the writer used cluster random sampling. The media used in this study was using flash animation as media to writing descriptive text. Wherever, firstly the experimental group and control group were given pretest, after that the experimental group was given treatment. The treatment namely is using flash animation as a media in writing descriptive text was done in three meeting. After the treatment was given, the writer gave post-test. To analyze the obtained data, the writer used t-test as a way to get different mean between the result of pretest and post-test and to test the hypothesis.

Based on the result of the calculation of t-test, it was found that the value of t-table (1.691) lower than t-test in Experimental group (8.61). It meant that the alternative hypothesis of the study is accepted and null hypothesis is rejected. In other words, the use of using flash animation as a media in writing descriptive text of the eighth students showed an effect.
\end{abstract}

Keywords: Flash Animation, Student' Ability, Writing, Descriptive Text.

\section{Introduction}

Writing is a form of communication to express the thought and feeling through writing. Writing is a tool to get along with the world [1]. Teaching and learning English, especially in writing skill is not an easy job. It needs hard work and enthusiasm from the teacher and learner. The success of the teaching process is determined by the quality of the teachinglearning process such as strategies, method and technique. The appropriate use of strategies, method and technique with the situation and condition of the students can be influential toward the students' level of understanding and performance in learning.

Most learners found that writing descriptive text is not easy. It occurs because they are not familiar with writing a text. Teachers have to facilitate the students to develop their skills especially in writing and help to solve the problems that might be found because writing can 
be acquired by experiencing through the practices. SMP Muhammadiyah Palangka Raya is one of the schools in Palangka Raya Central Kalimantan. In the syllabus for English subjects, especially for grade eight, students are required to have competency in writing some texts in English, one of which is descriptive text. However, based on the interview with some English teachers at the school regarding the problems confronted by their students in writing, the teachers stated that the students still have some difficulties in writing descriptive text such as the use grammar, organization, dictation, and reference to what will be written. No wonder if the students' writing are still far from the expectation.

The use of interesting media can help the learners to develop their ideas and writing skills. Most people are visually oriented and visual message is effective to clarify information [2]. The students can use picture or other visual aids as the media. Experts believe that visual aids facilitate the students in writing. Flash animation is one of the visual aids that can be used as a media. It will lead the learners to mental development; this is related to their ability of imagination and creativity in writing a text. Flash animation refers to an animated movie or clip created using Adobe Flash software (formerly Macromedia Flash). Using Flash Animation can help the students get a clear insight of what they would like to write down as a descriptive text. Somehow, the teaching and learning activities at this school have never tried using this strategy yet and merely rely on the material in the package book. This atmosphere never allows the students to play with their own and obligating to go along with the book contents which are probably or totally different from their real life.

This study was focused on thinking out the effect of Flash Animation on the students' ability in writing descriptive text of the eighth grade students. The objective of this study was to find out the effect of using flash animation on writing descriptive text of the eighth grade students at SMP Muhammadiyah Palangka Raya in academic year 2013/2014 and to find out whether there is any significant difference of learning outcome by using Flash Animation and those who are teaching without using Flash Animation in writing descriptive text for the eight grade students of SMP Muhammadiyah Palangka Raya.

\section{Literature Review}

\subsection{Writing}

Experts have discussed writing, and they have their own perception on writing but generally they all believe that writing is more than putting words into a sentence. Writing is communicative act with an intended purpose and audience which leads the learners or writer to experience finding a topic and developing written piece to be meaningful text [3]. In other words, writing is a process where the learners are challenged to find the most effective way to express their ideas in a piece of writing.

Writing means spacing between words; punctuation, including parentheses; typography, including style of typeface, italicization, underlining, upper and lower case, capitalization to indicate sentence beginnings and proper nouns; inverted commas, for example to indicate that a term is being use critically (chimpanzeez' "language" is...); graphics, including, lines, shapes, borders, diagrams, tables, abbreviations; logogram, for example; and layout, including, paragraphing, margin, pagination, footnotes, headings and subheading.

Descriptive text is a kind of text which can be seen from two sides: from its structure organization and from its function. From its structure organization, descriptive considers as a piece of writing that is written based on spatial order. However, from its function descriptive has a function to express meaning through a description. 


\subsection{Teaching and Learning Descriptive Text}

Teaching Writing is important to conduct. Learning to write well is very essential to improve communication skills, grammar and gives a special contribution to the way of critical thinking [4]. There are some goals of teaching writing. First, the introduction and practice of some form of writing provide students for different learning style and needs; so that, they feel more at ease and relax. Second, writing provides students with some real evidence that they make some progress in the language. Third, writing is likely a medium and also classroom activities. The last, writing is often needed for formal and informal testing [5].

Toendan [6] states that generic structure and grammatical pattern of descriptive text contains of:

1. Identification : Identifies phenomenon to be describe.

2. Description : Describes parts, qualities, characteristics.

3. Descriptive text uses simple present tense.

4. Focus on specific participants.

5. Use attributive and identifying process.

6. Frequent use of epithest and classifiers in nominal groups.

Descriptive text is a text which portrays the image of certain thing from which a writer wants to transfer it to the readers. Mostly descriptive texts depict or describe in words the image of certain person, animal, thing, and location or place. It is a text or speech that is meant to give a verbal picture of an object, character, location, or event. Descriptive text is a kind of text which can be seen from two sides: from its structure organization and from its function. From its structure organization, descriptive considers as a piece of writing that is written based on spatial order. However, from its function descriptive has a function to express meaning through a description.

\subsection{Teaching Writing by Using Media}

Media is important facility because it is used as a mediator between objective activity in learning process and the students.

According to Van Els [7], media are all aids which may be used by teachers and students to gain certain educational objective. Reiser and Dick [8] cited in Fathiyyaturrizqi [9] stated that the function of media are 1) saving time, which means that most media presentation requires a short time to transmit the message, 2) stimulating interest, 3) encouraging students' participation, 4) providing information and example, 5) helping students learn communicate ideas visually, 6) providing medium for individual group reports, and 7) making a classroom dynamic, relevant, and attractive.

\subsection{Developing of Using Flash Animation}

Flash is a household name when it comes to multimedia, flash is a program developed by Adobe (Formerly Macromedia), Inc. to produce multimedia web content and presentations. Flash Animation media is a media in form of animation. It is regularly employed in the form of movement and visual style which is designed with flash animation like frame to frame, button, movie clip, motion tween, etc.

Suciadi [10] stated that macromedia flash is a computer application program which is released by Adobe (Formerly Macromedia) Inc. The program is used to make vector and bitmap animation for interactive and dynamic media purposes. This application can also be 
used to load logo animation, movie, games, make a navigation in website, banner, animation button, interactive menu, screen server and make another web application.

According to Pramono [11], there are several advantages of using flash animation as a media of learning because flash has the following advantages:

1. The final result of the flash file has smaller size when compared to other media files.

2. Flash is able to import almost all image files and audio files so that the media can be more attractive.

3. Animations can be created, can be executed, and can be controlled.

4. Flash can create executable files (*. Exe) that can be run on any computer without having to install the flash program first.

5. Font of presentation will not change even if the PC used does not have those fonts.

6. Flash is a vector image that will never be broken though zoomed hundred times.

7. Flash can run on any operating system, like Windows, Macintos, Linux.

The end result can be changed or made by various forms, such as *. Avi, *. Gif, *,Mov, or other format file.

Based on the explanation above flash program is based on vector graphics, so the access is faster and looks smoother on the scale regardless to screen resolution. This program can also be filled with a bitmap imported from other programs. The advantage of flash animation media is the very small size but it can display an amazing animation. In addition, it can also be made with Flash cartoons and interactive applications that allow users to interact directly with the application made and the content of flash animation can be made according to the maker. The disadvantages of developing a media based on flash animation is need a long time for those who does not use design graphic program before, the language of program is difficult and less simple, but now in the bookstore sells the CD's form of flash especially noun materials. To facilitate students in understanding and identifying English vocabulary about the objects in the classroom, the application can be packaged in the form of images of objects and text.

\subsection{Hypotheses}

Based on the objective of the study, the hypotheses are:

$\mathbf{H}_{\mathbf{0}}$ : The flash animation which is used to teach descriptive text does not give any significant effect.

$\mathbf{H}_{\mathbf{a}}$ : The flash animation which is used to teach descriptive text gives a significant effect.

\section{Research Method}

This study belongs to Quasi-Experimental Design with Nonrandomized-Groups PretestPosttest Control Group Design. According to Wido [6], "Quasi-Experimental designs are not based on random assignments of subjects to experimental and control group. However, they attempt to compensate for this shortcoming through the careful scheduling of observation and treatments in such a way as to eliminate many of the threats to internal validity".

This study focuses only for two classes that were picked from the eighth grade students to be experimental group and control group in SMP Muhammadiyah Palangka Raya in academic year 2013/2014, hence there was no need for Random Assignment and this study was not pure experimental. They were taken as it was in the field of Experimental Group and Control Group without any manipulation or subjectivity matter. However, the writer took the sample 
randomly out of a box, where the sample was not individuals but naturally occurring groups (cluster sampling), that is class. The design is clarified as Figure 1.

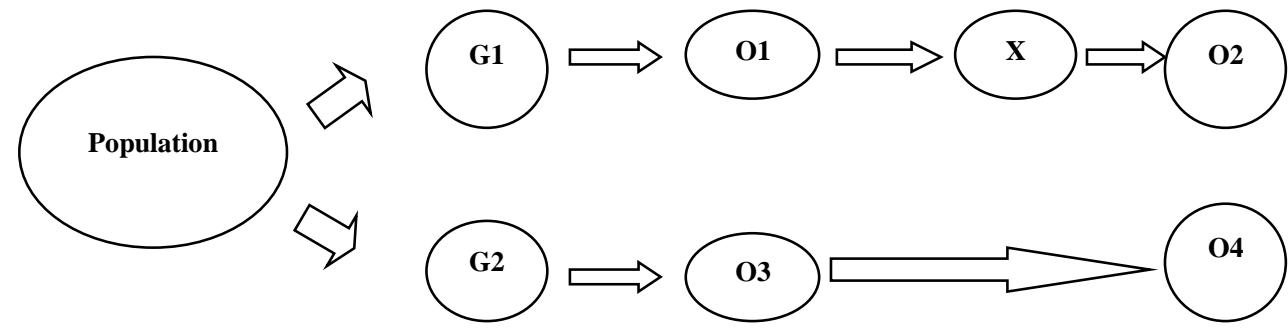

Fig.1. Nonrandomized-Groups Pretest- Posttest Control Group Research Design

Where:

G1 : Experimental group (Class VIII-1)

G2 : Control group (Class VIII-5)

$\mathrm{X} \quad$ : Treatment using flash animation

O1 : Observation of experimental group before receiving treatment

O2 : Observation of experimental group after receiving treatment

O3 : Observation of control group before conventional method

O4 : Observation of control group after conventional method

To analyze the data, Arikunto [12] suggested using T-Test, since the study compared the means of group by using pretest and post-test to know the differences of student's achievement before and after the treatment given.

\section{Research Finding and Discussion}

In this study, some tests were administered by pretest and post-test in both experimental class and control class. This study found that there was a difference between the pretest and post-test in the experimental and control class. There are two groups consist of Experimental group and Control group of the eighth grade students of SMP Muhammadiyah Palangkaraya. The hypotheses were to see whether or not the treatment in the experimental group gave significant effect compared to that of the control group which did not get the treatment. The treatment used flash animation media.

Based on the data analysis procedures, it can be seen that the flash animation media which was used to teach the eighth grade students of SMP Muhammadiyah resulted in a significant effect. It indicates that using flash animation media encourages the students to be more active and made learning writing easier, because they can make descriptive text from the picture in flash animation and they can grow their inspiration when they see a picture. In addition this media can help the students to apply the generic structure of descriptive text and when they received the treatment in teaching learning process indirectly the students learn about language features of descriptive text. So this media can help the students to apply the generic structure and language features in their paper which they write about descriptive text. It can be seen from the scoring of Pretest - Post-test Experimental Group and Pretest- Post-test of Control Group which have been calculated using the t-test formula. The result of t-test experimental group is 8.61 and the control group is 6.82. So, result of t-test Experimental 
Group is higher than t-test of Control Group. It means that flash animation media gives significant effect on the students' performance in writing descriptive text.

In addition, the result of t-test of pretest and post-test Experimental Group is compared with the value of t-table. If the result of t-test is higher than the value of $t$-table, the hypothesis is accepted. Conversely, if the result of t-test is lower than the value of t-table, the hypothesis is rejected. The result of the t-test calculation in this study shows that the score of t-test (8.61) is higher than the value of t-table (1.691). It means that the $\mathrm{H}_{0}$ was rejected and $\mathrm{Ha}$ was accepted.

\section{Conclusion}

Based on the result of the study and its discussion above, there are some points to be concluded:

1. The calculation of t-test score (8.61) was higher than $\mathrm{T}_{\text {table }}$ (1.691). It means that the $\mathrm{H}_{0}$ was rejected and $\mathrm{H}_{\mathrm{a}}$ was accepted.

2. The $\mathrm{H}_{0}$ was rejected and $\mathrm{Ha}$ was accepted, which means there was an effect of using flash animation media of the eighth grade students of SMP Muhammadiyah on their writing of descriptive text.

3. There was significant effect of writing improvement for control group that did not receive treatment compared to that of experimental group.

\section{References}

[1] Palmer. C, Barbara, Mary L. Hafner, and Marylin F. Sharp.: Developing Cultural Literacy through the Writing Process. Massachusetts, Allyn and Bacon (1994)

[2] Sudjana, Nana and Ahmad Rivai.: Media Pengajaran. Sinar Baru Algesindo, Bandung (2009)

[3] Brown, H. Douglas.: Teaching by Principles: An Interactive Approach to Language Pedagogy (2 ${ }^{\text {nd }}$ Edition). Addison Wesley Longman Inc, San Francisco, California (2001)

[4] Belden, Russonello and Stewart.: Americans Believe Writing skills are More Important than Ever: Helping Teachers Teach Writing Is a Priority for Most Americans (2007)

[5] Byrne, Donn: Teaching Writing Skills. $7^{\text {th }}$ Edition. Longman, London (1995)

[6] Toendan, Wido. H.: Reading Comprehension Two.Book Two. Global House, Bandung (2009)

[7] Van, Els, Theo: Applied Linguistics and the Learning and Teaching of Foreign languages. Edward Arnold, London (1984)

[8] Reiser, R.A and W. Dick.: Instructional Planning: A Guide for Teachers. Allyn and Baeon, London (1996)

[9] Fathiyyaturrizqi, Fithry: The Use of Movie in Teaching Narrative Writing Skill: A classroom Action Research at One of the Junior High Schools in Bandung. Unpublished Thesis Bandung. FPBS Universitas Pendidikan Indonesia (2010)

[10] Suciadi, Andreas: Menguasai Pembuatan Animasi dengan Macromedia Flash MX. Elex Media Komputindo, Jakarta (2003)

[11] Pramono, Andi: Presentasi Multimedia Dengan Macromedia Flash. Andi Offset, Yogyakarta (200)

[12] Arikunto, Suharsimi: Dasar-dasar Evaluasi Pendidikan. Bumi Aksara, Jakarta (2005) 